\title{
INVESTIGATION OF THE QUALITY OF RAW MILK FOR PRODUCTION OF PIROT KATCHKAVAL $^{1}$
}

\author{
Dragana Pešić Mikulec, M.P.Petrović, Dragana Ružić ${ }^{2}$
}

Contents : Mastitis in cows and sheep is a main sanitary and economic problem. Economic losses caused by mastitis are great. Each cow with mastitis gives 10 to $15 \%$ less milk. In literature data we found that infected quarters give by $21,3 \%$ less milk compared to healthy quarters, and in case of repeated infection even by $30 \%$ less milk. The somatic cell count bellow $500.000 / \mathrm{ml}$, when the secretion is normal and the microorganisms are absent may be latent infection, while in case when there are more than $500.000 \mathrm{cells} / \mathrm{ml}$ and pathogen microorganisms are absent it is nonspecific mastitis but when the pathogenic bacteria is present it is mastitis infection of udder. Determination of the somatic cell count without determination of the presence of pathogenic microorganisms streptococae, staphylococcus, Escherichia coli, micrococcus and some fungi is not valid result about the health state of udder in cows. In new regulations proposal it is suggested that raw milk can not contain more then 400.000 somatic cells $/ \mathrm{ml}$ in milk. Conditions of curing, mountain climate and nitrite on the geographical locality of Stara Planina qualify the milk from that region as hygienically correct and as milk with a good quality for production of native types of cheeses.

Key words: milk, katchkaval, somatic cells

\section{Introduction}

The history of stockbreeding and cheese production in the region of Stara planina is very old and present for over several hundreds of years. For animation of production katchaval of Pirot and the evolution of dairy production, the movement of cattle which reflected on the production of Pirot type of cheese is very important. Extensive livestock breeding on private farms is characteristic of this region according to Petrovic et al. 2004. In livestock mainly cows and sheep are reared, therefore cow and sheep milk is used as raw material in production of cheese. The reach of native production of milk existed up to nowadays Characteristics of autochthonic processing of raw milk in this high quality cheeses which can get the protection of geographical location and technology of production as a national brand which produce in dairy in Dojkinci. The research of many authors shows that this production was happen in summer on the hangar. Nowadays the katchaval produced in much reduced quality because of reduced cattle and old family, with autochthon was of production. For improved quality of products by the other thing it is very important examination of health state udder of cows and sheep's and the number of somatic cells in milk (Pešić et al., 1992; Gonzales-Rodrigues et al., 1995; Bergonnier et al., 1995). Purpose of our study was the research udder health cows and sheep's which milk is used for production of this kind of cheeses.

\section{Material and method}

Material for this work was the samples of row milk. The samples takes in summer and in winter part of the year. The samples of row milk take place in village Visoka Ržana, Rsovci and Dojkinci. The presence of mastitis and the mark of milk quality according to number of somatic cells valuation on the rolls present in than table 1. Use the microscope for numbering of somatic cells. Direct numbering of cells working on this was: on the microscope plate put by micropipette $0,01 \mathrm{ml}$ of milk and daub on the surface of $1 \mathrm{~cm}$.After draying of plate ( 24 hour) the plate was purified by ksilols $(5 \mathrm{~min})$, drying and fixating with ethanol. The plate was examined with microscope using the immersion objective. For detecting the right number of cells we determine the factors of microscope and the middle value the number of cells in one eye field. Yield from middle value the number of somatic cells in one eye field, factor of microscope and 100 were the value of number of somatic cells in $1 \mathrm{ml}$ of milk.

\footnotetext{
${ }^{1}$ Originalni naučni rad-Original scientific paper

2 Dr Dragana Pešić Mikulec, research associate, NIVS Beograd, dr Milan P. Petrović, scientific counselor, mr Dragana Ružić, research assistant, Institute for Animal Husbandrz, Belgrade - Zemun.
} 
Table 1. Evaluation the number of mastitis and the quality of milk according to number of somatic cell in the bulk milk samples $(2,1)$

The number of cell in the shell samples of milk/ Evaluation health of udder according to number of cells and middle value of number research quality of milk

To 200.000 cells/ml of raw milk

Without mastitis or individual cases distracted secretion / very good condition

\begin{tabular}{||l||l|}
\hline \hline To 200.000 to 350.000 cells $/ \mathrm{ml}$ of raw milk & Small number of individual cattle with mastitis/good \\
\hline \hline From 350.000 do 500.000 cells $/ \mathrm{ml} \mathrm{milk}$ & The great number of cattle with mastitis / not too well \\
\hline \hline Above 500.000 cell $/ \mathrm{ml} \mathrm{milk}$ & Problematic herd great rate of caws with mastitis/ bed \\
\hline \hline
\end{tabular}

According to study in literature microorganisms cause the mastitis belong to koliphorm bacteria (Gonzales R.M.C., Gonzalo C., Primitivo F., Carmens P., 1995), Pseudomonas aeruginosa, Staphylococcus agalactiae, Staphylococcus aurous and other staphylococcus bacteria, Corynebacterium pyogenes and the others. When the secretion is in disorder in udder the number of somatic cells is expanded more or less. Alongside with the rise and the number of microorganisms too especially psychrotrophic but it's happen a significant change in chemical composition of milk which may indicate on the quality of products of milk. Milk for production of cheeses have to take from the caws with health udder because the greater number of somatic cells follow the other changes in milk which influence on the longest coagulation time, weak elastic of curd, retest whey in curd, losses of casein and oil which go away with whey because of wrong curding. As one of reason this guise was the less quality of calcium and the greatest quantity of serum protein in milk, which closed the sponge in curd and inhibited whey gone. The rand man of cheeses is weak, because with whey losses essential and important substances in milk, and the Rand man cheeses is week, because it losses with whey essential matters of milk, shelf life of cheeses is reduced because of the expended moisture because of whey band

\section{Results and discussion}

Results of our investigation in relation to the number of somatic cells were shown in table 2 .

Table 2. The somatic cell count in milk examinees cattle

\begin{tabular}{||l||l||l||}
\hline Individual & Quote of udder & Log.the number of somatic cells /ml \\
\hline \hline 1 & FD & 4,70 \\
\hline \hline & FL & 4,84 \\
\hline \hline & BD & 4,84 \\
\hline \hline & BL & 4,47 \\
\hline \hline & FD & 4,65 \\
\hline \hline & FL & 4,54 \\
\hline \hline 3 & BD & 4,00 \\
\hline \hline & BL & 4,75 \\
\hline \hline & FD & 4,30 \\
\hline \hline & FL & 4,70 \\
\hline \hline & BD & 4,60 \\
\hline
\end{tabular}


The sample of milk which we search satisfies for health udder according to standard in table 1 as very good (Hogan J.S., Larry K.,Smith D.A.,Todhunter P.S., Schoenberger, 1990)Somatic cells were present in milk of every cow, but always was a different between the number of cells in health and in ill udder and the variation in number in the species of somatic cells. In milk we can find the following somatic cells: polimorphonuclear leukocyte as neutrophils eosinophils and basophiles, limphocite, monocot, epithelia cells laminated, cylindrical and pyramid shapes gigantic erythrocite cells and Nizin balls. The rise the number of somatic cells by the quarter of udder can appear in colostral phase, in the period of late lactation, when the lactation is expended because of sterility or maximum utilize caws up to samo telenje i kod staromuznih krava (European Community: Council Directive 92/46 EEC 1992 ). The number of somatic cells bulk milk which is prepared to cheeses production in dairy in Dojkinci is shown on table 3.

Table 3. The analysis of samples of raw milk prepared for production of cheeses.

\begin{tabular}{|c|c|c|c|}
\hline No & Log. Number of somatic cells & Log number of somatic cells & Log number of somatic cells \\
\hline Seasons & summer & autumn & winter \\
\hline 1 & 5.47 & 5.39 & 5.47 \\
\hline 2 & 5.39 & 5.25 & 5.54 \\
\hline 3 & 5.65 & 5.3 & 5.6 \\
\hline 4 & 5.17 & 5.54 & 5.39 \\
\hline 5 & 5.39 & 5.62 & 5.47 \\
\hline 6 & 5.65 & 5.44 & $\#$ \\
\hline 7 & 5.7 & 5.5 & $\#$ \\
\hline 8 & 5.63 & 5.32 & $\#$ \\
\hline 9 & 5.39 & 5.60 & $\#$ \\
\hline 10 & 5.54 & 5,17 & $\#$ \\
\hline 11 & 5.17 & $\#$ & $\#$ \\
\hline 12 & 5.08 & $\#$ & $\#$ \\
\hline
\end{tabular}

The samples of bulk milk in our experiment were according to Regulations. According to date from literature (Barbano et al., 1989) cytological parameters according to seasons agree with our date that in autumn the percentage of somatic cells were largest number of cells (Petrović et al. 2004).

High criteria EU for milk in relation to the number of microorganisms and the number of somatic cells according to regulation were for microorganisms less then $300.000(\log .5,47)$ but for number of somatic cells less then $400.000(\log .5,69)$ (Bergonier et al., 1995) apropos $500.000(\log .5,70)$ cell $/ \mathrm{ml}$ in raw milk. This stage by the separate quarters of udder, then bulk milk by individual caws the same as the collective point is need to follow in all seasons of the yearend especially when the producers complain on some problems in the technological part of producers (Anderson and Andrews, 1977).

On the microbiological analyses milk of caw, sheep's and goat we concluded very variable parameters for yests, mould, coliphorm bacteria but and the others microorganisms, and that is reason of unsatisfactory hygiene of breeding animal and the handshake with milk. $(1,3,5)$. All samples of milk agreeable to the regulations when the number of somatic cells were less then $500000(\log .5,70) / \mathrm{ml}$ (apropos $\log .5,7$ ) milk is according to regulations.

Beside the microbiological criteria which we research in milk suspicious on mastitis it is important the investigation the chemical parameters as: chlorine sugar number and physical chemical parameters of milk. (Ali et al.,1980). All this parameters should be according to the number of somatic cells because this parameters will change when the number of somatic cells is expended in milk ant the chemical parameters is the test of our correctness in the number of somatic cells. 
In the samples of milk we analyses the chlorine sugar number, the degree of sour, $\mathrm{pH}$ value and the number of somatic cells. In table 6 we can see the correlation between parameters of chlorine sugar number and the number of somatic cells in milk.

Table 4. Determined percentage of lactose, $p H$ value and sour in ${ }^{\circ} \mathrm{SH}$, percentage of chloride and florin sugar number.

\begin{tabular}{|c|c|c|c|c|c|c|}
\hline Animal & Quarter of udder & Lactose $\%$ & $\mathrm{pH}$ & Sour in ${ }^{0} \mathrm{SH}$ & Chloride \% & Chloral sugar number \\
\hline 1 & FD & 4,03 & 6,40 & 6,80 & 0,127 & 2,63 \\
\hline & $\overline{\mathrm{FL}}$ & 5,96 & 6,80 & 4,20 & 0,141 & 2,14 \\
\hline & BD & 4,68 & 6,20 & 7,80 & 0,120 & 2,97 \\
\hline & $\mathrm{BL}$ & 4,03 & 6,30 & 6,60 & 0,123 & 3,53 \\
\hline 2 & FD & 4,20 & 6,90 & 7,00 & 0,144 & 1,81 \\
\hline & FL & 5,76 & 6,60 & 6,20 & 0,134 & 2,22 \\
\hline & $\mathrm{BD}$ & 4,23 & 6,50 & 7,80 & 0,137 & 2,60 \\
\hline & $\mathrm{BL}$ & 4,66 & 6,80 & 6,20 & 0,141 & 2,58 \\
\hline 3 & FD & 5,57 & 6,40 & 6,00 & 0,127 & 2,36 \\
\hline & FL & 5,35 & 7,00 & 4,60 & 0,148 & 2,70 \\
\hline & $\mathrm{BD}$ & 5,35 & 7,00 & 4,60 & 148 & 2,70 \\
\hline & BL & 5,53 & 6,40 & 7,00 & 0,127 & 2,01 \\
\hline
\end{tabular}

According to our investigation the percentage of lactose in the samples of milk were from 4,03 to 5,96 percentage, $\mathrm{pH}$ value from 6,20 to 7,80 sour in ${ }^{0} \mathrm{SH}$ from 4,20 to 7,80 , chloride from 0,120 to 0,148 and chlorine sugar number from 1,81 to 3,53 and it was in the border characteristics for health udder.

\section{Conclusion}

On the basis of our researches we can conclude that the conditions of breeding, mountain climate and nutrition, raw milk from this region is satisfactory the criteria's for hygienic correctness and good quality milk, for production of autochthonic kind of cheeses with the protected geographical location.

1. The number of somatic cells in the samples of milk from single quarter of udder were from 10000 to 70000 cells $\mathrm{ml}$ which is according to literature dates belong to the category very good;

2. The number of somatic cells in bulk milk samples in autumn were from $150000(\log .5,17)$ to $450000(\log .5,65)$ cells $\mathrm{ml}$ and with the number of somatic cells which is the largest in autumn;

3. In the summer the number of somatic cells were from $120000(\log 5,08)$ to $500000(\log 5,70)$ cells $\mathrm{ml}$ of milk;

4. Number of somatic cells in winter period were 250000 (Log.5,39) to 400000 (log. 5,60)cells ml.

5. Chemical parameters which we determined were : percentage of lactose in the investigated samples was from 4,03 to $5,96 \%, \mathrm{pH}$ value from 6,20 to 7,80 sour in ${ }^{0} \mathrm{SH}$ from 4,20 to 7,80 , chloride from 0,120 to 0,148 and chlorine sugar number from 1,81 to 3,53 ;

The presence our research team in this areas settlements with old household contribute the education of establishment in the premeditation to recovery the udder with mastitis in the animals. 


\title{
ISPITIVANJE KVALITETA SIROVOG MLEKA NAMENJENOG PROIZVODNJI PIROTSKOG KAČKAVALJA
}

\author{
Dragana Pešić Mikulec, M. P.Petrović, Dragana Ružić
}

\section{Rezime}

Kvalitet sirovog mleka ima značajan uticaj na proizvodnju sira »kačkavalja« .Na Staroj planini kačkavalj se proizvodi autohtonim načinom prerade ali u ograničenim količinama zbog smanjenog stočnog fonda i staračkih domaćinstava. Karakteristike autohtone prerade mleka u ovaj vrlo kvalitetan sir koji može dobiti zaštitu geografskog porekla i tehnologije proizvodnje kao nacionalnog blaga vrši se u mlekari sela Dojkinci. Istraživanja mnogih autora pokazala su da je proizvodnja kačkavalja na Staroj planini bila razvijena naročito u letnjem periodu na pojatama. U zadatom periodu ispitivali smo broj somatskih ćelija u uzorcima kravljeg i ovčjeg mleka domaćinstava koja snabdevaju mlekaru u Dojkincima. Somatske ćelije smo ispitivali kao pokazatelj zdravstvenog stanja vimena muznih životinja. Mastitis tjs. oboljenje vimena kod krava i ovaca spada među najvažnije zdravstvene i ekonomske probleme koje se može otkiriti u subkliničkoj fazi na osnovu broja somatskih ćelija. Ekonomski gubici zbog mastitisa su veliki jer svaka krava sa mastitisom daje 10 do $15 \%$ manje mleka lošeg hemijskog sastava koji može nepovoljno uticati na tehnologiju proizvodnje sira.. $(7,2,4)$ Gubici predstavljaju i troškovi lečenja bolesne stoke, uklanjanje neizlečivih grla kao i loš kvalitet mleka za preradu. Cilj našeg ispitivanja u ovom radu bilo je ispitivanje stanja mlečne žlezde krava i ovaca čije mleko je služilo za proizvodnju ove vrste sira.

\section{Literature}

1. ALI A.E., ANDREWS A.T.,CHEESEMAN G.C.(1980):The influence of elevated somtic cell count on casein distribution and cheese making. J.Dairy Res. 47, 393.

2. ANDERSON M.,ANDREWS A.T. (1977):Progressive changes in individual milk protein concentrations associated with high somatic cell counts. J.Dairy Res. 44,223.

3. BARBANO D.M.,RASMUSSEN R.R.,LYNCH J.M.(1989) Influence of milk somatic cell count and milk age on cheese yield. J.Dairy Sci 74,369-388.

4. BERGONIER D., LAGRIFFOUL, G., CONCORDET D., BARILLET F., BERTHELOT X., (1995): Dynamique des infections mammaries subcliniques de la brebis laitiere en relation avec les comptages de cellules somatiques . Rencontre Rech. Rumin. 2, 299-302.

5. European Community: Council Directive 92/46 EEC of 16 June 1992 laying down the health rules for the production on the market raw milk, heat milk and milk base product, 1992.

6. International Dairy Federation (IDF): Milk payment system for ex-farm milk-Antibiotic testing-Mastitis control. Bulletin of International Dairy Federatio No 305(1995).

7. GONZALES R.M.C., GONZALO C., PRIMITIVO F., CARMENS P.(1995): Relationshep between somatic cell count and intramammary infection of the half udder in dairy ewes. J. Dairy Sci. 78, 2753-2759.

8. HOGAN J.S., LARRY K.,SMITH D.A.,TODHUNTER P.S., SCHOENBERGER S.(1990): Colaborative study to determine effects of milk comparative on somatic cell counts. J.Food Protect 53(1) 67-71.

9. PETROVIĆ P.M., DRAGANA RUŽIĆ-MUSLIĆ, ŽUJOVIĆ M., SKALICKI Z., PERIŠIĆ P (2004): Analysis of the livestock production system present on Stara planina mountain from the aspect of production of hard cheese-kackaval.. Biotechnology in Animal husbandry, vol 20, 1-2,81-89

10. PEŠIĆ DRAGANA, RAKIĆ M.,MIHALJEV ZORICA,STOJANOVIĆ L. (1992): Sezonsko praćenje bakteriološke i citološke slike mleka .Veterinarski glasnik 46(19,37)-40. 